\title{
Comparison of the Mini Mental State Examination and depressive symptoms between high cardiovascular risk and healthy community elderly groups
}

\author{
Amanda Lucas da Costa ${ }^{1,4}$, Juliana Santos Varela ${ }^{1}$, Osmar Mazetti, \\ Luciane Restelatto ${ }^{4}$, Andry Fitterman Costa ${ }^{4}$, Claudia Godinho, \\ Ana Luiza Camozzato', Paulo D. Picon ${ }^{4}$, Márcia L. Chaves ${ }^{1,2,3}$
}

\begin{abstract}
The aging of the population is a universal phenomenon with direct consequences upon the public health system. One of the main repercussions of the growth in this sector of the population is the increased prevalence of disorders such as dementia and depression which are very frequent among the elderly. The relationship between cardiovascular risk factors, dementia and depression have been addressed in many recent investigations. Objectives: To evaluate the relationship of cognitive performance and depressive symptoms with cardiovascular risk in the elderly. Methods: 94 high cardiovascular risk elderly patients and 160 healthy community elderly were evaluated cross-sectionally. The Mini Mental State Examination (MMSE) and the Geriatric Depression Scale (GDS-15) were used as the main measures. The cutoff for presence of depression was 6 on the GDS. Results: The high cardiovascular risk elderly group showed significantly lower scores on the MMSE $(\mathrm{p}<0.001)$ and was significantly associated to depression $(\mathrm{p}<0.001)$, independently of education. The logistic regression analysis for depression as the dependent variable, age and group (healthy community or high cardiovascular risk elderly) were kept in the final equation. Higher age (Odds Ratio $=0.92 ; 95 \%$ CI 0.86-0.98) and high cardiovascular risk elderly $(\mathrm{OR}=2.99 ; 95 \% \mathrm{CI} 1.36-6.59)$ were associated to depression. Conclusions: The present findings corroborate the different cognitive performance of elderly with high cardiovascular risk factors and the association of depressive symptoms with this group.
\end{abstract}

Key words: cognitive disorder, cardiovascular risk, Mini Mental State Examination, depressive disorders.

\begin{abstract}
Comparação do Mini Exame do Estado Mental e sintomas depressivos entre idosos de alto risco cardiovascular e saudáveis da comunidade

Resumo - O envelhecimento da população é um fenômeno mundial com conseqüências diretas no sistema de saúde pública. Uma das principais conseqüências do crescimento desta parcela da população é o aumento da prevalência de doenças como demência e depressão que são muito freqüentes entre os idosos. Recentemente, a relação entre fatores de risco cardiovasculares, depressão e demência foi abordada em várias investigações. Objetivos: Avaliar a relação de desempenho cognitivo e sintomas depressivos com risco cardiovascular em idosos. Métodos: 94 idosos de alto risco cardiovascular e 160 idosos saudáveis da comunidade foram avaliados num corte transversal. O Mini-Exame do Estado Mental (MEEM) e a escala de depressão geriátrica (GDS-15) foram usados para as medidas principais. O ponto de corte para presença de sintomas depressivos foi 6 na GDS. Resultados: O grupo de alto risco cardiovascular mostrou escores significativamente mais baixos no MEEM $(\mathrm{p}<0001)$ independente da educação, e foi significativamente associado a depressão $(\mathrm{p}<0,001)$. A análise de regressão logística para depressão como variável dependente, idade e grupo (idosos saudáveis da comunidade ou idosos de alto risco cardiovascular) foram mantidos na equação final. Maior idade (Razão de Chance=0,92, IC $95 \%$ 0,86-0,98) e idosos de alto risco cardiovascular ( $\mathrm{RC}=2,99$; IC 95\% 1,36-6,59) estavam associados à presença de depressão. Conclusões: Os achados do presente estudo corroboram o desempenho cognitivo diferencial dos idosos de alto risco cardiovascular e a associação de sintomas depressivos a este grupo.

Palavras-chave: transtorno cognitivo, risco cardiovascular, Mini-Exame do Estado Mental, transtorno depressivo.
\end{abstract}

${ }^{1}$ Dementia Clinic, Neurology Service, Hospital de Clínicas de Porto Alegre. ${ }^{2}$ Medical Sciences Post-Graduation Course, UFRGS School of Medicine. ${ }^{3}$ Internal Medicine Department, UFRGS School of Medicine. ${ }^{4}$ Centro de Dislipidemia e Alto Risco Cardiovascular (CDA) from Hospital de Clinicas de Porto Alegre.

Márcia Lorena Fagundes Chaves - Rua Ramiro Barcelos, 2350 / sala 2040 - 90035-091 Porto Alegre RS - Brazil. E-mail: mchaves@hcpa.ufrgs.br Received October 27, 2008. Accepted in final form November 22, 2008. 
The aging of the population is a universal phenomenon with direct consequences upon the public health system. As life expectancy increases, the number of demented patients worldwide is projected to grow from 24.3 million in 2001 to 81.1 million by $2040 .{ }^{1}$ Approximately 6 million Americans and 2 million Brazilians have Alzheimer's disease. ${ }^{2,3}$ $\mathrm{AD}$ is the $3^{\text {rd }}$ most expensive disease in USA, after heart disease and cancer, and is among the 10 leading causes of death among people $>65$ years' old in developed countries. ${ }^{2}$ Therefore, the identification of individuals at risk for developing dementia is essential. Early diagnosis allows therapeutic interventions, decreases families' level of stress, reduces incidental risk, increases autonomy and maybe in some cases prevents or retards dementia onset. ${ }^{4}$

Since depression and dementia are among the most common mental health problems in the elderly population, it is common to observe their comorbid presentation, which impacts quality of life, functional decline, increase in the use of health services, increase of morbidity and mortality. ${ }^{5}$ Depression is probably the most frequent cause of emotional distress and worsening of life quality among the elderly. ${ }^{6,7}$ This population is more prone to developing depression due to reduced social perspectives, health impoverishment, frequent losses, biological, vascular, structural and functional changes, besides neuroendocrine and neurochemistry dysfunction in the brain during aging. ${ }^{8}$ Therefore, development of elderly depression is multi-factorial in nature. ${ }^{5}$ The association between depression and dementia is also significant. Depressed elderly may present cognitive decline, besides an increased risk for progression to dementia. ${ }^{9}$

Over the last 3 decades, a decline of cardiovascularrelated mortality has been observed in developed countries, while relatively fast and substantial increases have occurred in developing regions, such as Brazil. According to the World Health Organization, the tendency for increase among developing areas may persist, worsening the scenario of already high morbidity and mortality. ${ }^{10}$ The higher risk for developing dementia is found among patients with conditions associated to increased cholesterol levels, such as cardiovascular diseases and atherosclerosis. ${ }^{11}$

Studies have been carried out seeking to better understand the role of atherosclerotic disease, dyslipidemia and hypertension, predictive factors of cardiovascular risk, in the development of cognitive deficit. The strong association between atherosclerosis and dementia, especially Alzheimer's disease, has previously been demonstrated. Patients with vascular disease have shown three-fold higher risk for developing dementia. ${ }^{12}$ Prospective studies have shown the relationship of atherosclerotic disease and cognitive decline among the elderly. It is presumed that atherosclerosis may cause neuronal damage through ischemic lesions, followed by inflammatory response that leads to neuronal degeneration. Another hypothesis is neuronal damage caused by hypoperfusion due to decreased blood flow in the brain. ${ }^{13}$ A higher frequency of brain ischemic events was found in dementia patients compared to non-demented individuals. In these patients, the observation of atherosclerotic plaques in major vessels presented strong correlation with deposition of neuritic plaques, whose main component is the B-amyloid protein associated to Alzheimer's disease. ${ }^{14}$ However, no association between generalized atherosclerosis and depression in the elderly was observed. ${ }^{13}$

The link between dyslipidemia and the occurrence of cognitive deficit has been previously evaluated. The role of higher levels of cholesterol was significant as a risk factor for dementia in middle-age patients, but not among elderly patients. ${ }^{12}$ The substantially lower risk of cognitive decline was demonstrated in patients over the age of 50 with the use of statins ${ }^{15}$. Adult hypertension increases the risk of dementia, especially when associated to hypercholesterolemia. ${ }^{16}$

Hypertension is associated to increased risk of dementia, and control with anti-hypertensives, mainly with angiotensin converting enzyme inhibitors, has demonstrated a significant reduction in the incidence of dementia. ${ }^{12}$ Diabetes is an independent predictor of risk of cognitive decline, and the metabolic syndrome, an important cardiovascular risk factor, plays a role as a predictor of risk for dementia. ${ }^{17}$

The association of depression to cardiovascular disease is based on convincing evidence. A bidirectional pathway was proposed for these diseases because depression is an independent risk factor for cardiovascular events, and is more prevalent in patients with these conditions. Depression aggravates vascular disease and is associated to poorer outcomes. ${ }^{18}$ The association between risk for cardiovascular events, and cognitive decline and depressive symptoms make screening in this population imperative.

The present study aimed to evaluate the relationship of cognitive performance and depressive symptoms with cardiovascular risk in the elderly. The performance on the Mini Mental State Examination and the Geriatric Depression Scale among a sample of dyslipidemic elderly outpatients with high cardiovascular risk and a sample of healthy community elderly was compared.

\section{Methods}

A cross-sectional study was carried out for the objectives under investigation. The sample was composed of 94 elderly recruited from the reference center for dyslipidemia and high cardiovascular risk (Centro de Dislipidemia e Alto Risco Cardiovascular) from Hospital de Clínicas de Porto Alegre along with 160 healthy community elderly drawn 
from a cohort within the catchment area of the same hospital. All participants were aged 60 years or more. Illiteracy was not an exclusion criterion for either of the groups.

All patients evaluated at the reference center for dyslipidemia and high cardiovascular risk underwent a detailed clinical examination with an emphasis on past or recent cardiovascular events, physical and neurological examination and laboratory tests. Total cholesterol, HDL cholesterol, LDL cholesterol, triglycerides, glucose, ALT, AST, GGTP, electrolytes, creatinine, uric acid and TSH were the blood tests evaluated.

The inclusion criteria for dyslipidemia among the high cardiovascular risk group were based on the clinical guidelines for treatment with statins for this disease developed by the Brazilian Health Ministry. ${ }^{19}$ One of the three following criteria ( $\mathrm{a}, \mathrm{b}$ or $\mathrm{c}$ ) had to be met for inclusion:

a) cholesterol LDL $>100 \mathrm{mg} / \mathrm{dl}$ plus acute myocardial infarction;

b) cholesterol LDL $>130 \mathrm{mg} / \mathrm{dl}$ plus one of the following situations: coronary heart disease evidenced by exercise testing or myocardial scintigraphy, previous myocardial infarction, coronary revascularization, or at least 30\% obstruction on coronary angiography; other atherosclerotic disease such as peripheral vascular disease with intermittent claudication or obstruction $\geq 50 \%$ on Doppler, aortic abdominal aneurysm and/or symptomatic carotid disease; diabetes mellitus; genetic syndromes - familial hypercholesterolemia and lipid disorder; higher Framingham score ( $\geq 9$ for men and $\geq 15$ for women);

c) cholesterol LDL $>160 \mathrm{mg} / \mathrm{dl}$ plus one of the following situations: Framingham score ( $\geq 6$ for men and $\geq 10$ for women); age $\geq 55$ years; hypertension; $\mathrm{HDL}<40 \mathrm{mg} / \mathrm{dl}$; cigarette smoking.

Patients with abnormal neurological examination or previous history of stroke and dementia were excluded from this group. All selected patients were using statins regularly.

The group of healthy community elderly was drawn from an ongoing cohort study. ${ }^{20}$ All selected participants fulfilled criteria for the healthy aging study and consented to participate. The inclusion and exclusion criteria are de-

Table 1. Participant selection criteria for the elderly community cohort.

\begin{tabular}{ll}
\hline Requirements for entry & Major exclusion criteria \\
\hline Functionally independent & Medical conditions \\
Gives informed consent & Myocardial infarction \\
Willing to participate in the follow-up & Diabetes mellitus \\
Score $=0$ on Clinical Dementia Rating Scale & Chronic pulmonary disorder \\
Score $>11$ on the Blessed & Chronic renal disease \\
Information-Memory-Concentration Test & Hypertension (supine blood pressure $>160 / 95)$ \\
& Active cancer \\
& Seizure disorder \\
& Stroke/transient ischemic attack \\
& Parkinson disease \\
& Other neurological disorders (LAS, MS, etc.) \\
& Major Surgeries \\
& Coronary bypass \\
& Carotid endarterectomy \\
& Psychiatric conditions (previously diagnosed) \\
& Schizophrenia \\
& Major affective disorder \\
& Phobias \\
Chronic anxiety \\
Alcohol or drug abuse \\
Vision and Hearing \\
Vision uncorrectable to 20/100 OU \\
Hearing loss (interferes with speech perception) \\
Other conditions \\
Significant head injury \\
Unexplained prolonged loss of consciousness \\
Use of medications impairing cognitive function \\
\hline
\end{tabular}


Table 2. Demographic and clinical data of high cardiovascular risk group and healthy community elderly group.

\begin{tabular}{lccc}
\hline & $\begin{array}{c}\text { High cardiovascular risk } \\
\text { elderly with dyslipidemia } \\
(\mathbf{n = 9 4 )}\end{array}$ & $\begin{array}{c}\text { Healthy community elderly } \\
(\mathbf{n = 1 6 0})\end{array}$ & $\mathbf{p}$ \\
\hline Variables & $66.3 \pm 6.2$ & $67.7 \pm 5.8$ & 0.062 \\
\hline Age $(\text { mean } \pm \mathrm{SD})^{*}$ & & & \\
Sex ${ }^{* *}$ & $60(63.8 \%)$ & $108(67.5 \%)$ & 0.551 \\
$\quad$ Female $(\mathrm{N} \%)$ & $2.4 \pm 6.49$ & $6.49 \pm 3.39$ & $<0.001$ \\
Education $(\text { mean } \pm \mathrm{SD})^{*}$ & $24.24 \pm 5.28$ & $25.46 \pm 3.22$ & $<0.001$ \\
MMSE $(\text { mean } \pm \mathrm{SD})^{*}$ & & & $<0.001$ \\
GDS $\left(\right.$ depression) ${ }^{* *}$ & $31(33 \%)$ & $18(11.3 \%)$ & \\
$\quad$ Yes $(\mathrm{N} \%)$ & & &
\end{tabular}

picted in Table 1. Briefly, participants underwent a standardized neuropsychological and neurological evaluation. A collateral informant was also used to verify the history. Subjects were excluded if they had age-related diseases or risk factors for cognitive impairment at baseline. All participants and their collateral informants had to report normal functioning in the community at study entry and were screened with the Clinical Dementia Rating scale. ${ }^{21,22}$ Participants with a CDR of 0.5 (suggestive of incipient dementia) or greater (suggestive of dementia) were excluded from the sample.

Demographic data, the Mini-Mental State Examina$\operatorname{tion}^{23-25}$ and the Geriatric Depression Scale (GDS-15) ${ }^{26}$ were assessed in both groups. Subjects were further categorized into those with or without depressive symptoms according to the cutoff of 6 on the GDS ${ }^{29}$

The study was approved by the Ethics Committee for Research of the Hospital de Clínicas de Porto Alegre. All subjects signed an informed consent.

\section{Data analysis}

The statistical analysis was performed by the Statistical Package for the Social Sciences (SPSS for Windows 13.0) software. Parametric variables were analyzed with Student's $\mathrm{t}$ test. The Chi-square test (with Yates correction or Fisher exact) was used for the association analysis. One-way ANOVA with covariance analysis and the logistic regression model were used as multivariate models.

\section{Results}

Comparison of demographic, MMSE score and presence or absence of depressive symptoms by GDS between the dyslipidemic patients with high cardiovascular risk and the community healthy elderly groups are displayed in Table 2 . Education was significantly higher in the healthy community elderly group $(\mathrm{p}<0.001)$. The dyslipidemia with high cardio-
Table 3. Logistic regression for depression outcome with age, group (healthy elderly or high cardiovascular risk elderly with dyslipidemia), education, MMSE and sex as independent variables.

\begin{tabular}{lcccc}
\hline Variables & $\mathbf{B}$ & Wald & $\mathbf{p}$ & OR $(95 \% \mathbf{C I})$ \\
\hline Group $^{*}$ & 1.096 & 7.403 & .007 & $2.99(1.36-6.59)$ \\
Education & -.044 & .513 & .474 & $0.96(0.85-1.08)$ \\
Age & -.083 & 6.693 & .010 & $0.92(0.86-0.98)$ \\
MMSE & -.056 & 1.643 & .200 & $0.95(0.87-1.03)$ \\
Sex & -.570 & 2.071 & .150 & $0.56(0.26-1.23)$ \\
Constant & 5.291 & 4.234 & .040 & 198.514 \\
\hline
\end{tabular}

${ }^{\star}$ High cardiovascular risk elderly with dyslipidemia was the reference group.

vascular risk elderly group showed significantly lower scores on the MMSE $(\mathrm{p}<0.001)$ and was significantly associated to depressive symptoms $(\mathrm{p}<0.001)$. On one-way ANOVA with covariance, group $(\mathrm{p}<0.001)$ and educational level $(\mathrm{p}<0.001)$ showed independent and significant effects on MMSE scores.

In the multivariate analysis (logistic regression) with depression as the dependent variable, age and group (healthy community or dyslipidemia with high cardiovascular risk elderly) were kept in the final equation (Table 3). Higher age (Odds Ratio $=0.92$; 95\% CI 0.86-0.98) and dyslipidemia among the high cardiovascular risk elderly group $(\mathrm{OR}=2.99 ; 95 \% \mathrm{CI} 1.36-6.59)$ were associated to depression.

\section{Discussion}

This study was carried out to analyze both cognitive performance measured by the Mini Mental State Examination (MMSE), and depressive symptoms using the Geriatric Depression scale (GDS) in high cardiovascular risk elderly with dyslipidemia and to compare results with healthy community elderly. We observed lower MMSE scores among the dyslipidemia with high cardiovascular risk elderly as well as greater depression in this group, indepen- 
dently of educational level. Vascular risk factors may impair cognitive functions and are related to the occurrence of not only vascular dementia but also Alzheimer's disease. ${ }^{12}$ The level of evidence for these associations is highest for hypertension and diabetes mellitus(DM), especially when these factors are assessed in middle age. ${ }^{17,27-29}$ However, the essential pathophysiological mechanisms were still not linked to clinical relevance. ${ }^{12}$ Several studies have highlighted the possible protective effect of antihypertensive therapy on cognition while some trials are assessing the effects of statins and treatments for insulin-resistance. . $^{15,30-33}$

In the logistic regression for depression controlled for education, both higher age and high cardiovascular risk elderly were risk factors. Elderly with dyslipidemia with high cardiovascular risk presented twice the risk of presenting depressive symptoms than healthy community elderly from the same age group.

Emerging evidence has suggested a causal relationship between atherosclerosis and both cognitive decline and depression in old age. ${ }^{34,35}$ In addition, neuropathologic findings indicate that subjects with cognitive impairment more often have vascular pathology $y^{36,37}$, whereas late-life depression has been associated with white matter hyperintensity on brain neuroimaging, assumed to be vascular in origin. ${ }^{18,38,39}$ Recognition of the relationship between cerebrovascular disease and depressive symptoms has led to the proposition of the term "vascular depression" to describe a clinical subtype of major depression characterized by apathy, psychomotor changes, and cognitive impairment in the presence of cerebrovascular disease demonstrated on neuroimaging or by focal neurological findings (e.g., mild hemiplegia, facial droop)..$^{9,40}$

Considering that cognitive decline, dementia and depressive symptoms are a worldwide problem, establishing preventive or curative treatment when available is a major health challenge, and vascular risk factors are a promising research pathway for these conditions.

\section{References}

1. Ferri CP, Prince M, Brayne C, et al. Global prevalence of dementia: a Delphi consensus study. Lancet 2005;366:2112-2117.

2. Alzheimer's Disease Statistics Fact Sheet, Alzheimer's Association, 2008.

3. Herrera E Jr, Caramelli P, Silveira AS, et al. Epidemiologic survey of dementia in a community-dwelling Brazilian population. Alzheimer Dis Assoc Disord 2002;16:103-108.

4. Petersen RC, Stevens JC, Ganguli M, Tangalos EG, Cummings JL, DeKosky ST. Practice parameter: Early detection of dementia: Mild cognitive impairment (an evidence-based review) Report of the Quality Standards Subcommittee of the American Academy of Neurology. Neurology 2001;56:1133-1142.
5. Ávila R, Bottino CMC. Cognitive changes update among elderly with depressive syndrome. Rev Bras Psiquiatr 2006;28: 316-320.

6. Sartorius N. The economic and social burden of depression. J Clin Psychiatry 2001;62 (suppl 15):8-11.

7. Berlim MT, McGirr A, Fleck MP. Can sociodemographic and clinical variables predict the quality of life of outpatients with major depression; Psychiatry Res 2008;160:364-371.

8. Almeida OP, Forlenza OV, Lima NK, et al. Psychiatric morbidity among the elderly in a primary care setting--report from a survey in São Paulo, Brazil. Int J Geriatr Psychiatry 1997;12: 728-736.

9. Alexopoulos GS, Meyers BS, Young RC, Campbell S, Silbersweig D, Charlson M. "Vascular depression" hypothesis. Arch Gen Psychiatry 1997;54:915-922.

10. Sposito AC, Caramelli B, Fonseca F, Bertolami MC. IV Diretriz Brasileira Sobre Dislipidemias e Prevenção da Aterosclerose Departamento de Aterosclerose da Sociedade Brasileira de Cardiologia. Arq Bras Cardiol 2007;88(Suppl 1):2-19.

11. Mohs RC, Cohen L. Alzheimer's Disease Assessment Scale (ADAS). Psychopharmacol Bull 1988;24:627-628.

12. Duron E, Hanon O. Vascular risk factors, cognitive decline, and dementia. Vasc Health Risk Manag 2008;4:363-381.

13. Vinkers DJ, Stek ML, van der Mast RC, et al. Generalized atherosclerosis, cognitive decline, and depressives symptoms in old age. Neurology 2005;65:107-112.

14. Roher AE, Esh C, Kokjohn T, Sue L, Beach T. Atherosclerosis and AD, Analysis of data from US National Alzheimes's Coordinating Center. Neurology 2005;64:494-500.

15. Jick, H, Zornberg, GL, Jick, SS, et al. Statins and the risk of dementia. Lancet 2000; 356:1627.

16. Kivipelto, M, Helkala, EL, Laakso, MP, et al. Midlife vascular risk factors and Alzheimer's disease in later life: longitudinal, population based study. BMJ 2001;322:1447.

17. Brands AM, Biessels GJ, de Haan EH, et al. The effects of type 1 diabetes on cognitive performance: a meta-analysis. Diabetes Care 2005;28:726-735.

18. Thomas AJ, Kalaria RN, O’Brien JT. Depression and vascular disease: what is the relationship? J Affect Disord 2004;79:81-95.

19. Picon PD, Polanczyk CA, Amaral KM. Protocolo Clínico e Diretrizes Terapêuticas para Dislipidemias do Ministério da Saúde. Access in www.saude.gov.br/sas/dsra/protocolos.

20. Chaves ML, Camozzato AL, Godinho C, Kaye J. Incidence of Mild Cognitive Impairment and Alzheimer's Disease in South of Brazil. J Geriat Psychiatry Neurol (in press).

21. Hughes CP, Berg L, Danziger WL, et al. A new clinical scale for the staging of dementia. Br J Psychiatry 1982;140:566-572.

22. Chaves ML, Camozzato A, Godinho C, et al. Validity of the Clinical Dementia Rating Scale for The Detection and Staging of Dementia in Brazilian Patients. Alzheimer Dis Assoc Disord 2007;21:210-217. 
23. Folstein MF, Folstein SE, McHugh PR. "Mini-mental state”. A practical method for grading the cognitive state of patients for the clinician. J Psychiatr Res 1975;12:189-198.

24. Chaves ML, Izquierdo I. Differential diagnosis between dementia and depression: a study of efficiency increment. Acta Neurol Scand 1992;85:378-382.

25. Brucki SM, Nitrini R, Caramelli P, Bertolucci PH, Okamoto IH. Suggestions for utilization of the mini-mental state examination in Brazil. Arq Neuropsiquiatr 2003;61:777-781.

26. Almeida OP, Almeida SA. Short versions of the geriatric depression scale: a study of their validity for the diagnosis of a major depressive episode according to ICD-10 and DSM-IV. Int J Geriatr Psychiatry 1999;14:858-865.

27. Launer LJ, Ross GW, Petrovitch H, et al. Midlife blood pressure and dementia: the Honolulu-Asia aging study. Neurobiol Aging 2000;21:49-55.

28. Knopman D, Boland LL, Mosley T, et al. Atherosclerosis Risk in Communities (ARIC) Study Investigators. Cardiovascular risk factors and cognitive decline in middle-aged adults. Neurology 2001;56:42-48.

29. Bellew KM, Pigeon JG, Stang PE, et al. Hypertension and the rate of cognitive decline in patients with dementia of the $\mathrm{Al}$ zheimer type. Alzheimer Dis Assoc Disord 2004;18:208-213.

30. Qiu C, Winblad B, Marengoni A, et al. Heart failure and risk of dementia and Alzheimer disease: a population-based cohort study. Arch Intern Med 2006;166:1003-1008.

31. Zuccalà G, Onder G, Marzetti E, et al. Use of angiotensinconverting enzyme inhibitors and variations in cognitive performance among patients with heart failure. Eur Heart J 2005;26:226-233.
32. Wolozin B, Kellman W, Ruosseau P, et al. Decreased prevalence of Alzheimer disease associated with 3-hydroxy-3methyglutaryl coenzyme A reductase inhibitors. Arch Neurol 2000;57:1439-1443.

33. Bernick C, Katz R, Smith NL, et al. Cardiovascular Health Study Collaborative Research Group. Statins and cognitive function in the elderly: the Cardiovascular Health Study. Neurology 2005;65:1388-1394.

34. O’Brien JT, Erkinjuntti T, Reisberg B, et al. Vascular cognitive impairment. Lancet Neurol 2003;2:89-98.

35. de la Torre JC. Is Alzheimer's disease a neurodegenerative or a vascular disorder? Data, dogma, and dialectics. Lancet Neurol 2004;3:184-190.

36. Snowdon DA, Greiner LH, Mortimer JA, Riley KP, Greiner PA, Markesbery WR. Brain infarction and the clinical expression of Alzheimer disease. The Nun Study. JAMA 1997;277:813-817.

37. Neuropathology Group of the Medical Research Council Cognitive Function and Ageing Study. Pathological correlates of late-onset dementia in a multicentre, community-based population in England and Wales. Lancet 2001;357:169-175.

38. Steffens DC, Krishnan KRR, Crump C, Burke GL. Cerebrovascular disease and evolution of depressive symptoms in the Cardiovascular Health Study. Stroke 2002;33:1636-1644.

39. de Groot JC, de Leeuw FE, Oudkerk M, Hofman A, Jolles J, Breteler MMB. Cerebral white matter lesions and depressive symptoms in elderly adults. Arch Gen Psychiatry 2000;57: 1071-1076.

40. Steffens DC, Krishnan KRR. Structural neuroimaging and mood disorders: recent findings, implications for classification, and future directions. Soc Biol Psychiatry 1998;43:705-712. 